\title{
Tandem One-Pot Synthesis of Polysubstituted Pyridines
}

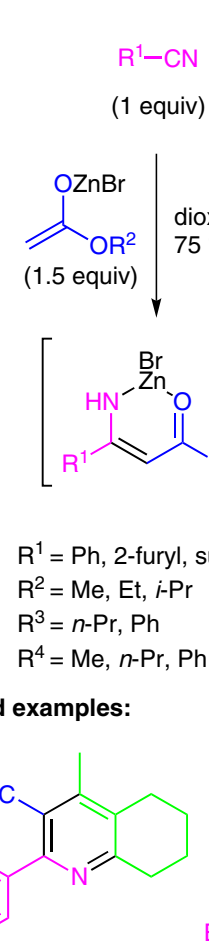

$92 \%$ yield<smiles>CCOC(=O)c1c(-c2ccccc2)nc2c(c1C)CCCC2</smiles>

$\mathrm{n}=1,90 \%$ yield $n=2,82 \%$ yield $\mathrm{n}=3,70 \%$ yield<smiles>CCOC(=O)c1ccc(-c2nc3c(c(C)c2C(=O)OC)CCCC3)cc1</smiles>

$77 \%$ yield<smiles>CCOC(=O)c1c(-c2ccccc2)nc2c(c1C)-c1ccccc1CC2</smiles>

$62 \%$ yield<smiles>CCOC(=O)c1c(-c2ccco2)nc2c(c1C)CCCC2</smiles>

$83 \%$ yield<smiles>CCOC(=O)c1c(-c2ccccc2)nc(C)c(-c2ccccc2)c1C</smiles>

$53 \%$ yield<smiles>Cc1cc(C(=O)O)c(C)c(C)n1</smiles>

up to $92 \%$ yield

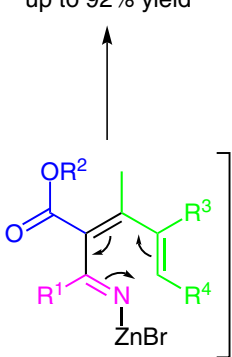

\section{SYNFACTing}

Significance: An efficient tandem one-pot process has been developed for the synthesis of polysubstituted pyridines with complete control of substitution patterns. The tandem reaction proceeds via the regio- and chemoselective addition of the Blaise reaction intermediate to the 1,3enyne followed by an isomerization-cyclizationaromatization process.

SYNFACTS Contributors: Paul Knochel, Christoph Sämann Synfacts 2012, 8(3), 0309 Published online: 20.02.2012 Dol: 10.1055/s-0031-1290218; Reg-No.: P00912SF
Comment: This convenient and straightforward process is characterized by high yields and its good functional group tolerance. The method described is very versatile due to various substitution patterns of the pyridine ring that can be generated. 